\section{Learning from climates past}

\section{Fixing Climate: What Past Climate \\ Changes Reveal About the Current Threat \\ - and How to Counter It \\ by Wallace S. Broecker and Robert Kunzig Hill and Wang: 2008. 272 pp. \$25}

As we are alerted to the perils of climate change, we need a long-term perspective to understand the capabilities of Earth's climate. Looking to the past can help us evaluate the risks and judge the best way to manage them.

Fixing Climate gives a personal account of scientific endeavours to understand past, present and future climate change. Geoscientist Wallace Broecker at the Lamont-Doherty Earth Observatory of Columbia University, New York, has teamed up with journalist Robert Kunzig to argue that the current crisis is urgent but not insurmountable, requiring technological development and political leadership. The authors use the analogy that dumping greenhouse gases into faced in the nineteenth century, an issue that also invited vehement debate at the time.

Few scientists have been as active in their work and outreach as Broecker. Starting with the atmosphere is akin to the sewage problem his upbringing and early career, Broecker explains what inspired him and outlines his tremendous contributions to climate science. Describing in an accessible way how Earth's climate system worked in the past, Broecker and Kunzig look at future climate predictions and the technological developments that may help to scrub the air clean.

Along the way, we meet some extraordinary characters. In 1896, the Swedish scientist Svante Arrhenius proposed that a doubling of carbon dioxide levels in the atmosphere would drive global temperatures up by nearly $6^{\circ} \mathrm{C}-$ close to the predictions made by today's climate models. Arrhenius did not foresee how quickly we would pump greenhouse gases into the air and took a benign (if naive) view of climatechange effects: "Our descendants, albeit after many generations, might live under a milder sky and in less barren natural surroundings than is our lot at present."

The broad topical coverage of Fixing Climate is admirable, yet there is a strong US emphasis. Climate-change adaptation and mitigation are not easily covered in a single popular text, as the authors admit. The book describes promising developments for stripping the air of excess carbon dioxide, but other avenues are less thoroughly explored. Little is made of the underlying problem that we are hooked on a high-energy lifestyle. Sustainable energy sources are underplayed despite the recent advances made, for example, with biofuels produced from algae and thin-film solar-power cells that are cutting the cost of these technologies.

There are some intriguing omissions from the book, notably the idea that humans may have influenced the climate for longer than we thought. In 2003, William Ruddiman of the University of Virginia, Charlottesville, proposed that more than 8,000 years of agriculture have raised atmospheric greenhouse-gas levels, warming the atmosphere by some $0.8^{\circ} \mathrm{C}$. This work is not discussed, even though it supports the underlying thesis of Fixing Climate that the past is the key to the future.

The book is a call to arms for us to take responsibility for our fossil-fuel dependency. The climate has changed; now let's fix this open sewer of the twenty-first century.

Chris Turney is professor in physical geography at the University of Exeter, Exeter EX4 4QJ, UK, and author of Ice, Mud and Blood: Lessons from Climates Past.

\title{
Mountains into molehills
}

\begin{abstract}
Burning the Future: Coal in America Screens on the Sundance Channel and is released on DVD on 13 May.

Mountain Top Removal

At the Fine Arts Theater, Asheville, North Carolina, on 15 May; on DVD in December.
\end{abstract}

Coal provides half of the United States' electricity. Increasing demand and eased regulation are fuelling coal-mining operations such as mountain-top removal, in which miners access coal seams, without digging below the surface, by dynamiting the summits of mountains and dumping the blasted rock in adjoining valleys.

Two new documentaries - Burning the Future: Coal in America by director David Novack and Mountain Top Removal from producer and director Michael O'Connell - investigate how mines affect health and the environment. They focus on the Appalachian mountains just inland of the eastern US seaboard, an area known for its traditional music, rural poverty and religious fervour.

The sight of demolished mountain tops is dramatic and well suited to the screen. Both films feature aerial shots of the mines, which

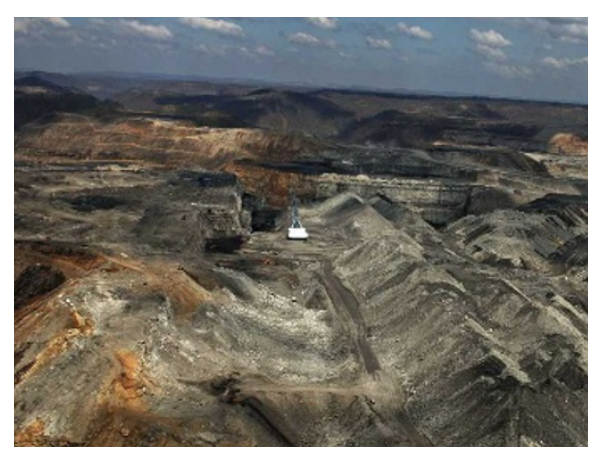

Mining companies move mountains to get to coal.

look as if someone has skinned the top halves of mountains down to the rock, then snapped off the peaks. Residents such as Ed Wiley of Coal River, West Virginia, are understandably upset: "Once these mountains are gone, there is no more Appalachia; there is no more West Virginia. It don't grow back."

In 2005, the Environmental Protection Agency estimated that $6.8 \%$ of forested land in Appalachia will be affected by mountaintop mining by 2012. According to Mountain Top Removal, 207,000 hectares of mountains have been destroyed and 1,900 kilometres of mountain streams have been buried. Mining companies are required to do some remediation of mined-out surface sites, although this is often waived, and in any case does not return the area to its former state.

Both films describe the mines as causing increased flooding in the valleys below, and polluting local water with toxins, including arsenic and lead. Chilling but anecdotal evidence charts the effects on the health of local people and on the school children of Marsh Fork elementary school in West Virginia. This school and many local individuals appear in both films.

Choosing to focus on the wound-like alteration to the landscape, the film-makers barely mention climate change, probably the most dire and far-reaching effect of the US coal habit. Nor do they discuss arguably worse mining methods elsewhere, like hard-rock mining for minerals such as gold and copper, which is undertaken on a much larger scale.

Both films stir up a sense of loss and outrage. But neither offers solutions - political or technical - beyond suggesting that coal companies resume underground mining, which they are unlikely to do voluntarily as it is less efficient. Coal companies would rather keep opening up a mountain like taking the top off an egg. Emma Marris is a correspondent for Nature. 